\title{
The Social Question in South Africa
}

\author{
From Settler Colonialism to Neoliberal-Era Democracy
}

Ben Scully

\begin{abstract}
INTRODUCTION
The classical social question of the nineteenth and early twentieth centuries is usually thought to pertain to Europe and North America, where the expansion of capitalist production brought social dislocation and political upheaval, especially in growing urban industrial centers. Yet South Africa experienced similar processes of industrial expansion and rapid urbanization in roughly the same period. Coupled with this, colonial occupation and racialized restrictions on land ownership dispossessed significant portions of the rural population from the land, precipitating a simultaneous crisis in the traditional agrarian economy, which the majority still relied on as a main source of livelihood. As a result, South Africa had its own version of the social question, the history of which provides a lens for rethinking the social question on a global scale.

In the Northern capitalist countries, conflict over the inequality and immiseration produced by capitalism led to the rise of labor movements as major political forces in many countries in the late nineteenth and early twentieth centuries. In many cases, labor movements were key actors in expanding formal democracy. This democratization can be thought of as one aspect of the Northern response to the social question, and it was followed by, in most places, the expansion of labor market protections and welfare provisions. By the mid-twentieth century, some form of a welfare state had been established in almost all advanced capitalist countries.

South Africa followed a different trajectory, which could be considered as a settler colonial response to the social question. Rather than an opening of a democratic political space, the late nineteenth and early twentieth centuries were marked by an institutionalization of racial inequalities that expanded citizenship for the white
\end{abstract}


minority and restricted it for the majority. Long-standing practices of segregation and racism came to be codified in law, as the state attempted to accommodate organized white workers whose demands for protection from the vagaries of the market included a demand for protection from labor-market competition with the black majority. During this period, South Africa's political movements pushing for democratization and economic justice usually framed demands in terms of antiracism and anti-colonialism rather, or in addition to, anti-capitalism. The rejection of the state's legitimacy forestalled demands for state social protection, and social policy implemented in the Apartheid era was often looked upon with suspicion.

Despite this history, South Africa is not just a negative example for thinking through the social question. The country achieved democracy in 1994, when the influence of neoliberal ideology was at its height. The new government faced the task of replacing the racialized social compact it had inherited at precisely the time when the mid-twentieth-century model of welfare states was coming under pressure in much of the rest of the world. In response to this challenge, South Africa has come to be a site of innovation both in policy and in scholarly debates on new forms of social protection.

This chapter will trace the changing meanings of and responses to the social question in South Africa. I concentrate on two key moments of state policy formation. The first part describes the settler colonial response to the social question, which emerged in the late nineteenth century and culminated in the formalized Apartheid system from the middle of the twentieth century. During this period, the expansion of capitalist development and colonial dispossession created crises of poverty and landlessness among the indigenous majority, as well as among a section of the white working class. However, the state's response was to define the social question as the "poor white problem." The policies that were implemented in this era aimed to protect white workers not only from the market in general but especially from competition with the black majority in the labor market. By giving white workers privileged access to the labor market, much of the work of social protection was accomplished through private employment, and explicit social policy was necessary only as a safety net to protect the few whites who could not gain security through wage work. This "solution" of the social question intensified the already established link between race and citizenship rights in the country.

The second part of this chapter will discuss the post-1994 democratic period, in which the contradictory forces of neoliberal ideology (at both the local and global levels) and a political and ideological imperative to expand access to social welfare for the previously excluded black majority have produced a new, neoliberal-era response to the social question. The liberalization of the economy from the 199os led to increasing informalization of work and rising unemployment. This meant that the labor market could not provide security to the majority in the post-Apartheid period as it had in the middle of the twentieth century for the minority. As a result, state-provided social protection became more important, but its growing role 
had to be reconciled with the neoliberal ideology that shaped economic policy after 1994 .

The third and final section of the chapter draws on my own research and secondary literature to show how gaps in the state's response since 1994 put pressure on households and other social connections, which highlight the continued relevance of the social question today.

\section{THE SOCIAL QUESTION IN THE SETTLER COLONY}

The nineteenth century as whole, even before the diamond and gold rushes, had been a period of conflict and dispossession across what is today South Africa. However, widespread, permanent landlessness remained a rarity, as did concentrated urban poverty. The Europeans' discovery of diamonds and gold in the latter half of the nineteenth century transformed the economy and society of southern Africa, creating widespread urbanization and proletarianization for the first time. The new demand for labor led to a number of policies that were aimed at undermining the economic security of the rural African population in order to compel them to seek wage labor. Subsidies for white farmers ensured that new opportunities for commercial farming afforded by growing urbanization would not be captured by the African peasantry. ${ }^{1}$ The 1913 Native Land Act went further by preventing Africans from owning or renting land outside of the 13 percent of the country set aside as "reserves." The group who were most affected by this restriction were Africans who had been operating under sharecropping arrangements on white-owned farms outside of these reserves. Such arrangements were banned in the Orange Free State and severely curtailed elsewhere. In total, one-fifth of the five million Africans in South Africa at the time were proletarianized by the act. ${ }^{2}$

The late nineteenth and early twentieth centuries also saw class differentiation among rural whites, with small-scale farmers being pushed out by larger enterprises. As a result, newly proletarianized African workers were joined in the urban labor market by growing numbers of landless Afrikaners. These two groups entered primarily into low-skilled wage work in the mines and related industries, like construction and transportation. The new mining industries also attracted skilled immigrants with mining experience in Europe and the gold-producing areas of North American and Australia. These workers formed the core of the first trade unions to develop in the urban centers. By the last decades of the nineteenth century, urban slums were a feature of almost all South African cities. John Iliffe notes that although these concentrated areas of urban poverty were multiracial spaces, "South Africa's rulers identified multiracial poverty as the Poor White Problem. Although destitute white men had long been numerous, they were first seen as a social problem - rather than as a victim of their vices—during the $1880 \mathrm{os}$ and 1890 , when new European notions of poverty as a social phenomenon mingled with South Africa's growing concern with racial categorization."3 
Already in the 1890 os city leaders in Johannesburg established a public works program and relief fund for poor Afrikaners. ${ }^{4}$ In 1906, also in Johannesburg, a group of white workers organized around the identity of the "unemployed," demanding support from the state. In response to these workers' protests, the city established a public works program to absorb the labor of unemployed urban whites. $^{5}$ Despite these developments, social protection remained piecemeal and uncoordinated at a national level. ${ }^{6}$

In the first decades of the twentieth century, trade unions began to emerge a serious political force. Major strikes, especially among white workers in the mines, but also including black dockworkers in Cape Town and Asian sugarcane workers in Natal, made industrial conflict a central issue of the early Union government. One outcome of these early strike waves was the emergence of private pensions and other forms of company-backed social protection, almost exclusively for white workers. Initially, however, the state's role remained limited.

In contrast to welfare provisions, labor law was coordinated by the state at the national level, and this period saw increasing attempts to formalize a legal system of industrial relations for the first time. National workers' compensation insurance was implemented in 1914. The Mines and Works Act of 1911 instituted basic protections for workers, including setting a limit on working hours, outlawing child labor, and giving government inspectors the ability to monitor and sanction safety violations. However, this law is most remembered not as an early example of workplace safety legislation, but rather for the fact that it was the first legal implementation of a color bar, which allowed skilled jobs to be reserved for white workers.

The juxtaposition of safety protections and legalized racial discrimination in the same law is emblematic of the way in which settler colonialism shaped South Africa's response to the social question. In this same period, in parts of the Global North, burgeoning labor movements were forcing reforms that mitigated both absolute poverty and the growing inequalities that accompanied capitalist growth. In South Africa, by contrast, both the politics of organized workers and the state's response to them served to deepen settler colonialism's pattern of racialized inequality. The African labor force had been created, in part, by undermining the security of African peasants, and the approach to labor and social protections did little to reverse this impact.

Early labor legislation barred black workers from striking (the 1911 Native Labour Act) and from participating in collective bargaining (the 1909 Industrial Disputes Prevention Act). White workers' demands for protection were frequently couched in racial terms. The first major strike on the gold mines, in 1907, was led by white workers fighting the use of Asian immigrant labor. Among the first agreements signed, once the mines recognized the white workers' union in 1918, was one that sought to halt the mines' practice of replacing skilled white workers with cheaper black workers, demanding that the ratio of seventeen black workers to every two higher-paid white workers - the earlier status quo-be continued. In 
1922, the Rand Revolt, a major general strike that spread into a mass insurrection against the government, was carried out under the slogan "workers of the world, unite and fight for a white South Africa."

Two years after the Rand Revolt, South Africa passed its first comprehensive industrial-relations legislation. The Industrial Conciliation Act of 1924 aimed to recognize trade unions in all industries and to formalize wage negotiations and dispute settlements between workers and employers. However, the law only applied to white workers, meaning black workers' wages and working conditions continued to be the prerogative of employers, and any improvements in the conditions of black workers relative to that of their white counterparts could be resisted in collective bargaining by white unions. Black trade unions were not illegal during this period. In fact, one of the most celebrated black trade unions in the first half of the twentieth century, the Industrial and Commercial Workers Union (ICU), reached its peak membership in the late 1920s. But the prohibition on black workers striking, and their exclusion from the institutions of collective bargaining, made organizing a challenge, as exemplified by the collapse of the ICU by the early 1930s. ${ }^{7}$

As more white workers were absorbed into privileged positions in the labor market, the workplace became increasingly important as a location of welfare provision. A means-tested national social pension was introduced in 1928 for white and colored workers, but it affected a relatively small portion of the white population, most of whom tended to have access to higher-value private pensions through their workplaces. ${ }^{8}$ In 1933 the state established the first national social welfare agency. The agency was initially situated within the Department of Labor, signifying the association between poverty and wage work. In 1937 Social Welfare was made an independent government department. Its primary programs were pensions and child welfare, but it also promoted the introduction of a limited unemployment insurance, which was instituted for white workers in $1945 .^{9}$

These developments left South Africa with a widespread social welfare system for white workers, even before the 1948 victory of the National Party that ushered in Apartheid as official state policy. Apartheid made explicit the racialized definition of the society that the state and social policy should serve. Whites were provided exclusive access to superior education, various basic state services, democratic representation, collective bargaining institutions, and institutions of social protection. Nonwhites were restricted, with inferior education; pass laws, which limited their physical movement (especially to cities); forced removal from areas designated for exclusive white residence; and a range of other forms of institutionalized disadvantage. In short, the state's response to the social question was bifurcated between protection for whites and repression for nonwhites.

However, the Apartheid government did give increasing attention to the social and economic lives of black South Africans, especially as a widespread crisis of social reproduction was developing in rural parts of the country as a result of the decline of rural economy that followed the 1913 Land Act. The government's 
main concern with this crisis was not the moral imperative to protect citizens, but the economic and political implications that would result from a collapse of rural economy. The centrality of "traditional" rural spaces to the social and economic lives of black people was a fundamental tenant of Apartheid ideology. The official justification, for example, of excluding black people from the state pension system was "the assumption that Native custom makes provision for maintaining dependent persons' in rural areas." ${ }^{10}$ The rural area was seen not only as a source of social security for black South Africans but also as important to the profitability of urban mining and industry. Mine companies openly argued that migrant workers' access to rural income allowed them to be paid lower wages in the cities. ${ }^{11}$

This idea of a rural source for black workers' social security was likely always little more than a convenient assumption on the part of employers and the Apartheid state, and it became increasingly difficult to reconcile with reality throughout the twentieth century. The Land Act and subsequent forced removals from "white" areas put enormous population pressures on the black rural areas, as the growing black population was restricted to the 13 percent of the land set aside as "native reserves." This led to overstocking of pastures, soil erosion, and other problems that undermined the viability of the reserve economies. Charles Simkins estimates that already by 1918 , the agricultural production of the reserves could meet less than 50 percent of the food requirements of residents. This proportion declined significantly, especially after $1950 .^{12}$

It is noteworthy that some of the main sources of data on the crisis of the reserve economies are reports and studies from the South African state itself. State officials were concerned with maintaining the reserves both as a source of labor for urban industry and as a viable place of residence for the African majority, who were legally prevented from permanently settling in cities. One response of the government was to promote industrial development in or near the reserves. For African residents, this policy offered an alternative to decreasingly viable agricultural activity. Concurrently, for the white government, this policy offered an alternative to the politically untenable relocation of African residents to main urban centers. From the 1950s, cities in and near the reserves were identified as "growth points," and businesses were offered tax breaks and subsidies to relocate production to these places. ${ }^{13}$ This support for the economies of the reserves was the flip side of the state's repressive answer to the social question for black South Africans. The developmental thrust of "separate development" was an attempt to preserve, and even strengthen, the self-sufficiency of the reserves, which was necessary to underpin the settler colonial response to the social question.

\section{SOCIAL QUESTION IN A NEOLIBERAL-ERA DEMOCRACY}

The settler colonial resolution to the social question was remarkably successful for the white citizens who were its primary beneficiaries. By the latter part of the 
TABLE 10.1 Key aspects of the policy base of racialized inequality under Apartheid.

\begin{tabular}{|c|c|c|}
\hline Policy Sphere & Metric of Inequality & Description \\
\hline \multirow[t]{2}{*}{ Education } & Spending per Pupil & $\begin{array}{l}\text { Spending levels per pupil were ten times higher in white } \\
\text { schools than in schools for black Africans. }{ }^{1}\end{array}$ \\
\hline & $\begin{array}{l}\text { Teacher-Student } \\
\text { Ratio }\end{array}$ & $\begin{array}{l}\text { "In } 1987 \text {, whereas the student-teacher ratios for whites } \\
\text { was } 16 \text { to } 1 \text {, that for blacks in so-called white areas was } \\
41 \text { to } 1 \text {, and for KwaZulu [a Bantustan or reserve area] } \\
\text { primary schools was } 53 \text { to } 1 \text { and KwaZulu secondary } \\
\text { schools } 37 \text { to } 1 . "\end{array}$ \\
\hline \multirow[t]{2}{*}{ Labor Market } & $\begin{array}{l}\text { Collective } \\
\text { Bargaining Rights }\end{array}$ & $\begin{array}{l}\text { Collective bargaining was established for white workers in } \\
\text { 1924. Black workers were prevented from participating in } \\
\text { bargaining and were excluded from agreements reached } \\
\text { until the 1980s. }\end{array}$ \\
\hline & $\begin{array}{l}\text { Job Reservations/ } \\
\text { Color Bar }\end{array}$ & $\begin{array}{l}\text { Through a range of legislation, occupational categories in } \\
\text { a number of industries were segregated by race, with black } \\
\text { workers restricted to low and semi-skilled positions while } \\
\text { skilled and managerial positions were reserved for whites. }\end{array}$ \\
\hline \multirow[t]{2}{*}{ Social Policy } & Pension Levels & $\begin{array}{l}\text { When pensions for black South Africans were first } \\
\text { introduced, in 1944, their levels were set at one-tenth the } \\
\text { level of white citizens' pensions. Although racial disparity } \\
\text { in pensions decreased through the Apartheid era, levels of } \\
\text { pay were not uniform until 1993. }\end{array}$ \\
\hline & $\begin{array}{l}\text { Unemployment } \\
\text { Insurance }\end{array}$ & $\begin{array}{l}\text { A nonracial unemployment insurance scheme was } \\
\text { established in 1947, just before the Apartheid government } \\
\text { came to power, but was amended in } 1949 \text { to exclude } \\
\text { black workers }{ }^{4} \text { who did not gain access to unemployment } \\
\text { assistance again until the late } 1970 \text { s. }^{5}\end{array}$ \\
\hline
\end{tabular}

\footnotetext{
${ }^{1}$ Edward B. Fiske and Helen F. Ladd, Elusive Equity: Education Reform in Post-Apartheid South Africa (Washington, DC: Brookings Institute Press), 5.

${ }^{2}$ J. Keith Chick, "Safe-Talk: Collusion in Apartheid Education," in Society and the Language Classroom, ed. H. Coleman (Cambridge: Cambridge University Press, 1996), 33.

${ }^{3}$ Van der Berg, "South African Social Security," 488.

${ }^{4}$ Iliffe, The African Poor, 141.

${ }^{5}$ Van der Berg, "South African Social Security," 491.
}

twentieth century, absolute poverty was virtually eliminated among the white population. Whites had enjoyed many decades of state policy aimed at advantaging them over nonwhite South Africans in the areas of education, land, employment, health, and security (see table 1). A testament to the Apartheid state's success in this regard is the durability of whites' advantages, even after two decades of explicit policy aimed at reducing racial inequalities.

However, while the system was successful for its white beneficiaries, its unraveling was, at least in part, a result of its failure to answer the social question of the black majority. Waves of protests from workers and students in the 1970s marked the beginning of a sustained anti-Apartheid protest movement, which eventually 
achieved the victory of nonracial democratic elections in 1994. This was the height of the period of neoliberal economic ideology. While neoliberal ideas shaped social pacts across the world, South Africa is a uniquely complicated example of a state tackling the social question under neoliberalism. The political moment of the new democracy compelled the state to deliver tangible improvements in the lives of the black majority, but the promises of freedom had to be realized within the constraints of a neoliberal global political economy.

As the previous section showed, labor and welfare policy were building blocks of white advantage in the pre-Apartheid period of rapid industrialization and urbanization. However, between these twin pillars of racialized social policy, it was labor laws that gave the strongest support for a white advantage. In the context of sustained economic growth through the mid-twentieth century, the labor market became the primary engine of inequality, while the welfare state acted as a buffer for white workers who fell through the cracks. In the democratic neoliberal era, labor and welfare policy remained the primary levers of addressing the social question, this time for all citizens. However, their relative importance was reversed. The informalization of wage work and the decline of the manufacturing sector in the face of global competition meant that the state had limited ability to deliver on its election promise of "a better life for all" through the labor market. It was, however, able to expand the already significant welfare state that it had inherited from the Apartheid government.

This is not to say that the post-Apartheid state has not been concerned with labor law or the world of work. One of the first major pieces of legislation passed by the democratic government was the Labour Relations Act (LRA) of 1995. This act made a firm commitment to collective-bargaining institutions and promoted co-determination in the governance of workplaces. However, the hopeful vision behind the law has never been realized. Collective bargaining has been implemented in unionized sectors, but it has done little to move workers out of the "Apartheid wage structure" that confines a significant portion of the employed working class to poverty. ${ }^{14}$ For the majority of workers who are not covered by collective bargaining, there have been even fewer improvements. A recently introduced national minimum wage is a recognition that these workers have not been able to improve their own situation through bargaining, and unions have expressed disappointment with the low level at which it has been set $\left(\mathrm{R}_{3,500 \text {, or }}\right.$ roughly US\$250 per month).

The failure of the new industrial relations system to improve workers' situations is partially explained by the growth of precarious forms of labor since 1994. The 1980 s had already been a period of economic crisis for the Apartheid state. The immediate post-Apartheid economic policy, inspired by the neoliberal orthodoxy of the time, tended to exacerbate, rather than alleviate this crisis. ${ }^{15}$ South Africa has experienced a transformation of its labor market, with declining absolute levels of employment in both mining and agriculture; the only significant employment 
growth has taken place in the retail sector, which is dominated by precarious work. ${ }^{16}$ While levels of employment have remained steady in manufacturing, there has been a major trend toward precaritization. Some formally unionized manufacturing industries have been decimated by the removal of tariff protections, with clothing and textiles being the most dramatic example. ${ }^{17}$

This situation has led some scholars to talk about a growing "representation gap" in the private sector, where increasing sections of workers don't have the associational power necessary to utilize the bargaining structures, which were set up with a very different workforce in mind.$^{18} \mathrm{~A}$ further blow to the functionality of the legal system of industrial relations has been the crisis within the Congress of South African Trade Unions (COSATU), the country's largest union federation, which has been plagued by factionalism and splintering. This situation gives little hope that the labor market can play the same role for the neoliberal-era social question that it did in the settler colonial period. As a result, the importance of welfare and social policy has been magnified. Because of the power of neoliberal ideology when South Africa achieved democracy, a major expansion of state-provided social welfare was unlikely to gain widespread support. However, the democratic government was fortunate to inherit one of the more widespread social welfare systems among middle-income countries. Since 1994 there has also been the introduction of new forms of state social support, but not without debates and resistance, which serve clarify the contours of the neoliberal-era social question.

A major plank of the post-Apartheid welfare system, the old-age pension, was actually put in place by the outgoing Apartheid government on the eve of democratic elections. The pension first introduced for white and colored workers in 1928 was expanded to all races by the 1940s, although at much lower levels for nonwhites. As the Apartheid system came under political siege in the 1970s and 1980 s, the state began to move toward eliminating racial biases in an attempt to gain some legitimacy. ${ }^{19}$ Throughout the 1980 os the value of pensions for black South Africans was increased while the value of whites' pensions was decreased, and by 1993 pension levels were equalized across races. The democratic government has largely maintained the pension system. It has even increased the value of pension in real terms after 1994; and in 2008 the pensionable age for men was lowered from sixty-five to sixty (making it equal to the age for women).

Yet other aspects of the inherited welfare system could not simply be maintained and expanded. The second largest social grant program of the Apartheid era, the support for poor mothers with young children, remained skewed toward white beneficiaries. While the law did not explicitly set different grant levels based on race, a number of logistical challenges were put in the way of nonwhite women (in particular, rural black women), who would otherwise qualify for the grant. The most significant barrier was that the grant required a court judgment to be obtained that demonstrated that the mother had no other sources of support. Rural black women had far less access to courts than did their urban white counterparts. 
In 1996, recognizing the racial bias of the grant, the new government established a commission to look into reorganizing the grant for children. The main concern of the state was that simply expanding access to the majority of the citizens at given benefit levels would be exceedingly expensive. Therefore, the commission's proposal, which eventually was implemented, was to expand access, but at a significantly reduced grant value. However, COSATU was strongly against this solution, and their resistance prompted a brief but important debate about the appropriate form of a post-Apartheid welfare state.

COSATU was not against the child grant itself, but the federation pointed out the virtual absence of a system of protection against long-term unemployment in a country that had one of the highest unemployment rates in the world. Rather than simply a "piece-meal tinkering with the elements of the inherited, fragmented social security network," ${ }^{\circ}$ COSATU argued for "restructuring the social welfare system." ${ }^{21}$ COSATU's position highlighted the inadequacies of a welfare system set up by the Apartheid government in the mid-twentieth century for a democratic country in a neoliberal global economy. In particular, COSATU called for new forms of protection for the unemployed, which had been poorly developed in the Apartheid era.

The Apartheid state had used labor market tools to ensure that unemployment was no more than a residual social problem among the population who were included in the settler colonial social compact. The national Unemployment Insurance Fund, which had been first introduced in the 1940s, was aimed a short-term cyclical unemployment. ${ }^{22}$ This had little effect in a post-Apartheid situation, where unemployment fluctuated between 25 percent and 30 percent. Furthermore, this unemployment was, in part, a legacy of Apartheid-era social policy. The restriction of education and job mobility for black workers before 1994 left South Africa with a workforce dominated by low-skilled workers. The liberalization of the economy after 1994 put these workers in competition with much cheaper low-skilled workers elsewhere in the world. ${ }^{23}$

One of the solutions that COSATU proposed for rethinking the welfare state in light of the post-Apartheid unemployment crisis was the introduction of a Basic Income Grant (BIG). The BIG was to be a universal monthly payment that, although small in value, would take a step toward decommodifying livelihoods in an environment where the labor market had proven to be an insufficient at regulating access to basic needs. Some of its supporters called it a "solidarity grant" 24 and trumpeted it as a form of 'citizen's income' that acknowledges a kind of nationwide membership and solidarity that would go beyond such (often empty) political rituals as voting to include rights to subsistence and consumption." ${ }^{25}$ In this sense, the debate about reformulating the welfare system was a debate about the way in which social policy would structure social inclusion and citizenship in the neoliberal era.

The proposal for a BIG received widespread support from unions, churches, and other sections of civil society. It was even recommended by the 
government-appointed Taylor Commission, which was established to evaluate the post-Apartheid social policy framework. Yet the proposal was never implemented and never even received the backing of the ruling ANC party. ${ }^{26}$ Instead, the government went ahead with the reforms to the child grant, which is now the second largest social grant in terms of value and the largest in terms of recipients. The ANC government's skepticism of the BIG reflected an enduring commitment to the idea of wage work and to the labor market as a key vehicle of social inclusion, even in a situation where work was not able to serve this function for a significant section of the population. ${ }^{27}$

An adherence to market logic has also shaped the expansion of access to basic government services. One of the most onerous legacies of Apartheid that the post1994 government had to address was the extreme imbalances in the provision of housing and services. Large sections of both urban and rural areas where black South Africans lived were not provided with national and municipal services such as water and electricity. While the new government has achieved a significant expansion of connections to both water and electricity, the provision of these services has been marketized, meaning that many poor households remain unable to access these basic needs, despite being connected to national and municipal infrastructure.

Apartheid policies that limited urban housing construction, in an attempt to slow urbanization, also left an enormous housing backlog, estimated by the government to be between 3 and 3.7 million houses in $1999 .{ }^{28}$ Since 1994 the government has undertaken an enormous project of building new low-cost housing for the poor, and by 2010 it had completed between 2.3 and 2.8 million houses. ${ }^{29}$ Unlike water and electricity, government houses are usually provided free of cost.

The ANC government's solution to the neoliberal social question has established access to services and grants as a defining feature of citizenship for poor South Africans. It has come to be understood as a right, with social movements and community protests often explicitly linking the demand for social welfare provisions to the act of voting. For example, beginning with the Landless Peoples Movement's campaign for a boycott of the 2004 national elections (under the slogan "No Land! No Vote!"), calls for election boycotts have become a standard tactic of social movements. In 2009 the Durban shack-dwellers movement Abahlali baseMjondolo used the slogan "No Land! No Houses! No Vote!" and the AntiPrivatisation Forum of Johannesburg included demands for electricity and water in their boycott campaign. ${ }^{30}$

\section{COOPERATION AND CONFLICT: SOCIAL PROTECTION BEYOND POLICY}

The expansion of grants and access to services has built a relatively extensive system of social welfare in South Africa in comparison to other middle-income 
countries in the Global South. However, the system remains inadequate to meet even the basic needs of the country's poor. A major portion of the burden of protection has fallen onto the households of the masses of unemployed and working poor in the country. Households have become an important social space in which the neoliberal-era social question is addressed. However, in contrast to Apartheidera assumptions about traditional forms of social protection among African families, households are not simply sites of altruism and communalism. The pressures that poverty and unemployment have placed on households has fueled conflict as much as cooperation. This section will discuss the household-level social protection that has become so important. It will also touch on other non-policy social spaces in which the social question is present, namely, spiraling personal debt, patronage and protest at the level of local government, and xenophobic violence.

The most significant gap in the post-Apartheid social policy framework is the lack of significant direct support for the working-age unemployed. As table 2

TABLE 10.2. Structure of state social protection in post-Apartheid South Africa.

\begin{tabular}{|c|c|c|c|c|}
\hline $\begin{array}{l}\text { Vulnerable } \\
\text { Group }\end{array}$ & $\begin{array}{l}\text { Programs in } \\
\text { Place }\end{array}$ & Eligibility & $\begin{array}{l}\text { Approximate } \\
\text { Number of } \\
\text { Beneficiaries }\end{array}$ & $\begin{array}{c}\text { Coverage of Total Eligible } \\
\text { Population }\end{array}$ \\
\hline The Elderly & $\begin{array}{l}\text { Old Age } \\
\text { Pension }\end{array}$ & $\begin{array}{l}\text { People over sixty- } \\
\text { five who live in } \\
\text { households that } \\
\text { meet a means } \\
\text { test. }\end{array}$ & 3.25 million & $\begin{array}{l}\text { Covers the vast majority } \\
\text { of older people, including } \\
80 \text { percent of age- } \\
\text { eligible black Africans. } \\
\text { Technically means-tested, } \\
\text { but in practice, this only } \\
\text { excludes a small portion } \\
\text { of age-eligible recipients. }\end{array}$ \\
\hline $\begin{array}{l}\text { Children } \\
\text { in Poor } \\
\text { Households }\end{array}$ & $\begin{array}{l}\text { Child Support } \\
\text { Grant }\end{array}$ & $\begin{array}{l}\text { Caregivers of } \\
\text { children under } \\
\text { eighteen who live } \\
\text { in households } \\
\text { that meet a } \\
\text { means test. }\end{array}$ & 12.02 million & $\begin{array}{l}\text { A means-tested grant. } \\
\text { There are some problems } \\
\text { with means and age } \\
\text { eligible recipients not } \\
\text { applying, }{ }^{2} \text { but overall, } \\
\text { an estimated } 85 \text { percent } \\
\text { of poor children are } \\
\text { covered. }{ }^{3}\end{array}$ \\
\hline The Disabled & Disability Grant & $\begin{array}{l}\text { People with } \\
\text { disabilities } \\
\text { whose spouses } \\
\text { meet a means } \\
\text { test and who } \\
\text { do not receive } \\
\text { another grant for } \\
\text { themselves. }\end{array}$ & 1.08 million & $\begin{array}{l}\text { Coverage difficult to } \\
\text { estimate because of } \\
\text { ambiguities in the } \\
\text { definition of disabled, but } \\
\text { a much larger portion } \\
\text { of disabled people are } \\
\text { covered now than under } \\
\text { Apartheid. }^{4}\end{array}$ \\
\hline
\end{tabular}




\begin{tabular}{|c|c|c|c|c|}
\hline $\begin{array}{l}\text { Vulnerable } \\
\text { Group }\end{array}$ & $\begin{array}{l}\text { Programs in } \\
\text { Place }\end{array}$ & Eligibility & $\begin{array}{l}\text { Approximate } \\
\text { Number of } \\
\text { Beneficiaries }\end{array}$ & $\begin{array}{c}\text { Coverage of Total Eligible } \\
\text { Population }\end{array}$ \\
\hline \multirow[t]{2}{*}{$\begin{array}{l}\text { The } \\
\text { Unemployed }\end{array}$} & $\begin{array}{l}\text { Unemployment } \\
\text { Insurance Fund }\end{array}$ & $\begin{array}{l}\text { People who lose } \\
\text { their job and who } \\
\text { have previously } \\
\text { contributed to the } \\
\text { fund can claim } \\
\text { for a period based } \\
\text { on their previous } \\
\text { contributions. }\end{array}$ & $\begin{array}{l}\text { Approximately } \\
100,000- \\
200,000 \text { at any } \\
\text { given time }\end{array}$ & $\begin{array}{l}\text { As few as } 1.3 \text { percent } \\
\text { of the unemployed are } \\
\text { covered. }{ }^{6}\end{array}$ \\
\hline & $\begin{array}{l}\text { Expanded } \\
\text { Public Works } \\
\text { Programme }\end{array}$ & $\begin{array}{l}\text { Unlike the } \\
\text { other programs, } \\
\text { EPWP eligibility } \\
\text { is not a right. } \\
\text { There are no } \\
\text { clear guidelines } \\
\text { governing where } \\
\text { projects are } \\
\text { implemented and } \\
\text { how beneficiaries } \\
\text { are selected. }\end{array}$ & $\begin{array}{l}\text { Approximately } \\
1 \text { million per } \\
\text { year }^{7}\end{array}$ & $\begin{array}{l}\text { In } 2015 \text { there were } 1.1 \\
\text { million beneficiaries of } \\
\text { EPWP }^{8} \text { who got short- } \\
\text { term (four to six months) } \\
\text { part-time jobs against } 7.4 \\
\text { million unemployed. }{ }^{9}\end{array}$ \\
\hline
\end{tabular}

${ }^{1}$ Anne Case and Angus Deaton, "Large Cash Transfers to the Elderly in South Africa," The Economic Journal 108, no. 450 (1998): 1330-1361; Justine Burns, Malcolm Keswell, and Murray Leibbrandt, "Social Assistance, Gender, and the Aged in South Africa," Feminist Economics 11, no. 2 (2005): 103-115; Margaret Ralston, Enid Schatz, Jane Menken, Fransisco Gomez-Olive, and Stephen Tollman, "Who Benefits-Or Does Not-From South Africa's Old Age Pension?" International Journal of Environmental Research and Public Health 13, no. 85 (2016): 1-14.

${ }^{2}$ Department of Social Development, South African Social Security Agency, and UNICEF, The South African Child Support Grant Impact Assessment (Pretoria: UNICEF South Africa, 2012).

${ }^{3}$ International Labour Organization, "South Africa’s Child Support Grant: A Booster for Poverty Reduction," April 14, 2016, www.ilo.org/global/about-the-ilo/newsroom/features/WCMS_468093/lang--en/index.htm.

${ }^{4}$ Gabrielle Kelly, Regulating Access to the Disability Grant in South Africa, 1990-2013, CSSR Working Paper 330, Centre for Social Science Research (Cape Town: University of Capetown, 2013).

${ }^{5}$ Haroon Bhorat, Sumayya Goga, and David Tseng, "Unemployment Insurance in South Africa," Africa Growth Initiative Working Paper 8. (Washington, DC: The Brookings Institution, 2013), 11.

${ }^{6}$ Geeta Kingdon and John Knight, "Unemployment in South Africa: The Nature of the Beast," World Development 32 , no. 3 (2004): 5 .

${ }^{7}$ Department of Public Works, Annual Report 2014/2015 (Tswane Central: Republic of South Africa, 2015).

${ }^{8}$ Ibid.

${ }^{9}$ Stats South Africa, Quarterly Labour Force Surveys, www.statssa.gov.za.

shows, coverage is reasonably good for the elderly, poor children, and the disabled. However, for the unemployed, there are only two programs available, the Unemployment Insurance Fund (UIF) and the Expanded Public Works Programme (EPWP). Both cover only a small portion of the total unemployed. The UIF is available only to those who previously had formal work and paid into the fund, and even then, the duration of benefits is limited. UIF is not available to those who 
have never been employed, workers in the informal sector, government employees, and the long-term unemployed. ${ }^{31}$

Given this gap, other social grants, and the old-age pension in particular, have become a de facto safety net for the long-term unemployed and underemployed. These grants reach the working-age unemployed through household and familial connections. A range of studies drawing on different data sets have shown that one of the most common strategies for coping with unemployment is to join or remain in the households of grant recipients in order to have some access to income. ${ }^{32}$ The informal welfare system of the household is a gendered one. Women's pensions have been shown to have a positive influence on the health of children in poor households, an effect that does not extend to pensions paid to men.

Grants are often used as a base from which to develop other income sources. Contrary to the common view that social grants disincentive wage work, the South African old-age pension has been shown to be positively associated with both migration and employment of working-age household members. ${ }^{33}$ This is evidence of what might be called "reverse remittances." In the Apartheid era, young male migrants would send remittances to support family who remained in rural areas. However, in the present, older grant recipients often use their grant to support younger family members migrating to urban areas. Because unemployment and short-term informal work are so prevalent, rural-to-urban migrants might have to be supported for some time, often years, before they can find work.

However, to say households are important is not to suggest that they are a panacea to the challenges of poverty and precarity. The increased significance of resource allocation within the household leads, in many cases, to increased conflict. ${ }^{34}$ Fakier and Cock have described a "crisis of social reproduction" that has developed within poor households, in which the female household members who bear the burden of caregiving are unable to compensate for the inadequacies of the labor market and basic service provision. ${ }^{35}$ Individuals and households do draw on mutualistic ties of solidarity at the community level, but even these are put under strain in situations of extreme poverty. ${ }^{36}$ Erik Bähre has described mutualistic savings societies in Cape Town as being characterized by "reluctant solidarity," which is as conflictual as it is cooperative, based not on "extensive unifying bonds of comradeship, but [on] small bonds fraught with social tension." ${ }_{37}$

In addition to the social connections of the household and community, formal debt has become an increasingly central feature of the economic lives of many South Africans. Poor households often rely on informal lenders, who charge very high interest rates, sometimes reaching triple figures. ${ }^{38}$ Social grant recipients are often the most reliable customers of informal lenders, since they have a more regular source of income than the precarious and informally employed. It is not unusual for grant recipients to pay a significant portion of their payment to lenders on a monthly basis. However, the most heavily indebted are not the most poor, but the lower middle class, especially civil servants and low-level salaried employees 
whose access to a steady wage allows them to gain credit with formal lenders. ${ }^{39}$ The primary causes of debt for these borrowers are payments for major life events, such as marriage, funerals, or higher education for their children..$^{\circ}$ The student protests that swept the country in the latter part of 2015 demanding free tertiary education highlighted the enormous anger and anxiety over the financial barriers to universities, which are seen as gateways to some level of financial security and stability.

Karl von Holdt, in a study of protest and violence around local government across South Africa, has argued that these struggles are, in part, marked by contestation over the meaning and content of citizenship. The most extreme form of this contestation is both individual and collective violence, which has led von Holdt to characterize South Africa as a "violent democracy." ${ }^{41}$ Community violence in South Africa takes place at multiple levels. On the one hand, there is the upwardoriented violence against the state, which explicitly advances demands for protection and inclusions. This is often intertwined with horizontal violence against political opponents, which seeks to gain or protect access to the state for particular individuals or groups. Finally, there is downward-oriented xenophobic violence, which has become a feature of South African struggles in recent years. In 2008, a wave of attacks against foreigners across the country killed sixty-two people and displaced thousands. In the years since then, periodic smaller waves of attacks have been a regular occurrence, as is the daily reality of a widespread popular resentment of non-South Africans among a significant portion of the country's citizens. The xenophobic violence is an explicit expression of subaltern contestation over the boundaries of inclusion.

The violence and conflict that is present in so many social spaces in South Africa is evidence of the degree to which the neoliberal response to the social question has pushed the burden of insecurity into the social spaces of households, communities, and the market. However, even in these private spaces, the informal systems of protection bear the imprint of state policy. Grants, connections to local government, and the identity of "citizen" are all resources that are drawn upon, and contested, in the livelihood strategies of poor South Africans.

\section{CONCLUSION}

South Africa's history provides a microcosm of the social question when considered at a global scale. The initial dislocations of capitalist growth led to a system of citizenship-based protection for a privileged minority, while the demands of the majority were dealt with through a combination of repression and developmentalism. Eventually, contestation from below opened up new democratic space, which was accompanied by new forms of generalized social protection. However, the social benefits of democracy were limited by changes in the labor market, which had been a primary vehicle of protection for the privileged minority of the past, 
but now came to be marked by widespread insecurity and exclusion. As a result, families and communities have become spaces of informal social protection and conflict.

At a global scale, the contemporary situation has made clear what was always obvious in the South African context: twentieth-century answers to the social question are inherently exclusionary and cannot be universalized across the world. However, the contemporary limits of the neoliberal-era social question are not set in stone. The neoliberal economic orthodoxy that constrained South Africa's policy options in its early years of democracy were thoroughly discredited by the 2008 financial crisis. South Africa is one of the many places where welfare protections have been expanded and new types of provision, not linked to the labor market, have been debated (for example, the BIG) or implemented (the child grant) over the past twenty years. At the same time, demands for seemingly "old-fashioned" social protection, such as a national minimum wage and increased access to affordable health care, stand beside new visions, such as basic income protection.

An important factor in whether and how these new directions are pursued is the protection and extension of democratic spaces. Earlier answers to the social question were accompanied by limited expansion of democracy. In the neoliberal era in South Africa, as in many countries around the world, the social benefits of democracy were limited by the global constraints that neoliberalism placed on state actions. In the current moment, it seems possible that such limits could be challenged, as evidenced by contemporary debates in South Africa such as those raised by recent student protests, which raise possibilities that extend significantly beyond the limits of neoliberal orthodoxy. However, an equally plausible possibility is that the limited gains of democracy lead to frustration and disillusionment with the state, leaving space for corruption, empty populism, and other political forces that are unlikely to push forward answers to the still-pressing social question of contemporary global capitalism.

\section{NOTES}

1. Sampie Terreblanche, A History of Inequality in South Africa, 1652-2002 (Scottsville, South Africa: University of KwaZulu-Natal Press, 2002), 259.

2. Terreblanche, History of Inequality, 262.

3. John Iliffe, The African Poor: A History (Cambridge: Cambridge University Press, 1987), 116-17.

4. Ibid., 118.

5. Charles Van Onselen, New Babylon New Nineveh: Everyday Life on the Witwatersrand 1886-1914 (Johannesburg: Jonathan Ball, 2001), 338-41.

6. Iliffe, African Poor, 118.

7. Philip Bonner, "The Decline and Fall of the ICU: A Case of Self-Destruction?" in Essays in Southern African Labour History, ed. Edward Webster, 114-20 (Johannesburg: Raven Press, 1978), 116-17.

8. Servaas van der Berg, "South African Social Security under Apartheid and Beyond," Development Southern Africa 14, no. 4 (1997): 486.

9. Bonner, "Decline and Fall of the ICU," 116-17. 
10. Social Security Committee, cited in van der Berg, "South African Social Security," 487.

11. Harold Wolpe, "Capitalism and Cheap Labour-Power in South Africa: From Segregation to Apartheid," Economy and Society 1, no. 4 (1972): 434.

12. Charles Simkins, "Agricultural Production in the African Reserves of South Africa, 1918-1969," Journal of Southern African Studies 7, no. 2 (1981): 256-83.

13. Hermanus S. Geyer, "Industrial Development Policy in South Africa-The Past, Present and Future," World Development 17, no. 3 (1989): 380.

14. Neil Coleman, "Towards New Collective Bargaining, Wage and Social Protection Strategies in South Africa-Learning from the Brazilian Experience." Global Labour University Working Paper, 2013.

15. Giovanni Arrighi, Nicole Aschoff, and Ben Scully, "Accumulation by Dispossession and Its Limits: The Southern Africa Paradigm Revisited," Studies in Comparative International Development 45, no. 4 (2010): 410-38.

16. Abhijit Banerjee, Sebastian Galiani, Jim Levinsohn, Zoë McLaren, and Ingrid Woolard, "Why Has Unemployment Risen in the New South Africa?" Economics of Transition 16, no. 4 (2008): 724.

17. Sarah Mosoetsa, "The Consequences of South Africa's Economic Transition: The Remnants of the Footwear Industry," in Beyond the Apartheid Workplace: Studies in Transition, ed. Edward Webster and Karl Von Holdt, 317-34 (Scottsville, South Africa: University Of KwaZulu-Natal Press, 2005).

18. Edward Webster and Rahmat Omar, "Work Restructuring in Post-Apartheid South Africa," Work and Occupations 30, no. 2 (2003): 194-213.

19. Van der Berg, "South African Social Security."

20. COSATU, "Audit of COSATU Positions on Social Security," 2000, www.cosatu.org.za/show. php?ID=2167.

21. COSATU Oral Submission to Portfolio Committee on Welfare, Regarding Proposed Changes to the System of Child Support Benefits Arising from the Report of the Lund Committee on Child and Family Support," Cape Town, April 21, 1997, www.cosatu.org.za/docs/subs/1997/childsupportbenefits. pdf.

22. Van der Berg, "South African Social Security under Apartheid and beyond."

23. Arrighi, Aschoff, and Scully, "Accumulation by Dispossession and Its Limits."

24. Guy Standing and Michael Samson, A Basic Income Grant for South Africa (Cape Town: University of Cape Town Press, 2003).

25. James Ferguson, Expectations of Modernity: Myths and Meanings of Urban Life on the Zambian Copperbelt (Berkeley: University of California Press, 1999), 158.

26. See Leila Patel, Social Welfare and Social Development in South Africa (Cape Town: Oxford University Press, 2005), 141-43, for an overview of these debates.

27. Franco Barchiesi, "Wage Labor and Social Citizenship in the Making of Post-Apartheid South Africa," Journal of Asian and African Studies 42, no. 1 (2007): 39-72.

28. Kate Tissington, "A Resource Guide to Housing in South Africa 1994-2010: Legislation, Policy, Programmes and Practice" (Johannesburg: SERI, 2011).

29. Ibid.

30. "No Electricity, No Vote, Say Protesters," Mail and Guardian, October 30, 2008. https://mg.co. za/article/2008-10-30-no-electricity-vote-say-protesters.

31. Haroon Bhorat, Sumayya Goga, and David Tseng, "Unemployment Insurance in South Africa: A Descriptive Overview of Claimants and Claims," DPRU Working Paper 13/160. Development Policy Research Unit, 2013, https://ideas.repec.org/p/ctw/wpaper/1316o.html.

32. Stephan Klasen and Ingrid Woolard, "Surviving Unemployment without State Support: Unemployment and Household Formation in South Africa," Journal of African Economies 18, no. 1 (2009): 1-51.

33. Cally Ardington, Anne Case, and Victoria Hosegood, "Labor Supply Responses to Large Social Transfers: Longitudinal Evidence from South Africa," Working Paper, National Bureau of Economic Research, September 2007, www.nber.org/papers/w13442. 
34. Sarah Mosoetsa, Eating from One Pot: The Dynamics of Survival in Poor South African Households (Johannesburg: Wits University Press, 2011).

35. Khayaat Fakier and Jacklyn Cock, "A Gendered Analysis of the Crisis of Social Reproduction in Contemporary South Africa," International Feminist Journal of Politics 11, no. 3 (August 18, 2009): 353-71.

36. Mosoetsa, Eating from One Pot.

37. Erik Bähre, "Reluctant Solidarity: Death, Urban Poverty and Neighbourly Assistance in South Africa," Ethnography 8, no. 1 (2007): 52.

38. Mosoetsa, Eating from One Pot.

39. Deborah James, "Money-Go-Round: Personal Economies of Wealth, Aspiration and Indebtedness," Africa: The Journal of the International African Institute 82, no. 1 (2012): 20-40.

40. Ibid., 20.

41. Karl von Holdt, "South Africa: The Transition to Violent Democracy," Review of African Political Economy 40, no. 138 (2013): 589-604. 